\title{
Using the 7Cs Framework for Designing MOOCs in Blended Contexts - New Perspectives and Ideas
}

\author{
Bettina Buch", Rene B Christiansen, Dorrit Hansen, Anne Kristine Petersen, Randi Skovbjerg Sørensen \\ Center for Teaching \& Learning, University College Absalon, Denmark
}

Copyright $\bigcirc 2018$ by authors, all rights reserved. Authors agree that this article remains permanently open access under the terms of the Creative Commons Attribution License 4.0 International License

\begin{abstract}
Designing teaching in an era of educational technology calls for new models for designing learning opportunities. The 7Cs framework developed by Professor Gráinne Conole and her colleagues provides a tool for discussing learning designs for online learning environments. In this paper, we introduce the 7Cs framework put forward by Conole and colleagues and discuss it in relation to the concept of personalized learning paths and 'schooling' as a discourse. The article is mainly theoretical, but as empirical support for our theoretical arguments, we discuss examples from a MOOC developed for the teacher education program at University College Absalon, Denmark. On this background, we propose a number of revisions for the 7Cs framework in order to adapt it for designing MOOCs that are used in blended contexts.
\end{abstract}

Keywords MOOC, Blended Learning, the 7Cs Model, Schooling, School as Discourse

\section{Introduction and Aim}

This paper aims to discuss a framework put forward by Professor Gráinne Conole and her colleagues, the so-called 7Cs framework. We will look into the development of the framework, as well as the current version, to suggest some changes to improve the model so that it may be used for designing MOOCs used in blended learning contexts. We will do this in two steps. Firstly, we will discuss the 7Cs framework as it appears now and propose a number of relevant changes to the framework. Secondly, we will discuss the concept of "schooling" as a specific discourse and the consequences this discourse may have for designing blended learning MOOCs.

When designing teaching using design-based principles, it can be useful to analyze the design as consisting of different stages. This is done, for instance, by Susan McKenny and Thomas C. Reeves, who use the concepts of the intended, implemented and the attained design [1] By intended design the authors refer to the way the designers of the design meant it to be. The implemented design is the way the intention is carried out and the attained design is the final outcome measured, for instance, by student satisfaction or grades [1].

To develop the intended design one can make use of different theoretical models as a support for the design process. Gráinne Conole et al. present the 7Cs framework as a tool for designing learning processes. The framework has gone through several changes, and the final version was presented in 2013.

At the same time, when designing MOOCs or online teaching in general, the notion of adaptive learning designs and personalized learning paths are essential in supporting students' in their individual learning processes [2]. This has been of particular interest in Denmark, because all teachers must have formal teaching competencies in the subjects they teach before 2020. To solve this in-service teacher training challenge, which affects around 10,000 teachers in need of formal training, University College Absalon has developed a MOOC as an economical way of training many teachers while at the same time acknowledging their expertise as experienced teachers who might have taught a given subject for many years without possessing the formal qualifications for doing so. The MOOC format is useful for personalized learning, and the course takes into consideration that the teachers have different skills and bring with them different experiences gained through their years of employment as teachers.

Comparing the intended MOOC design with the implemented MOOC design, we recognize that the personalized learning paths were difficult for the students, as well as the educators, to follow. It calls for the $7 \mathrm{Cs}$ framework to be refined to better fulfill its purpose, at least when used for designing blended formats. 


\section{Materials and Methods}

To investigate the use and suggestion for revision of the 7Cs framework, we consulted theories on teaching and learning in school as well as on designing teaching and learning in online environments. To support our theoretical discussions, we collected and analyzed data from four modules in a MOOC in the subject 'Teaching Subject Danish' ${ }^{1}$, a course that prepares students to teach L1 learning in Danish primary schools. The target group of the MOOC is in-service teachers who have more than two years of experience and who work as teachers while doing their studies, but who lack the formal qualifications in the subject. To obtain these qualifications, they can study the subject through the MOOC, which is intended to be completed in a blended format alternating between online studies and biweekly face-2-face meetings through two semesters.

Our analyses in this paper are based on the students' written material derived from a digital learning platform (Moodle), communication from news forums and other forums on Moodle, including lesson plans, email-correspondences between the educator and the students and observations in class. All data are analyzed according to theories of the school as a discourse with its own ways of "doing and being". We bring forward this empirical pool of data in the text below as a discussion tool for approaching the 7Cs framework.

\section{The Development of the 7Cs Framework}

In an undated blogpost, Conole describes a new model for designing learning processes, which she calls "a new learning design methodology" [3]. This design methodology is aimed at designing learning processes using modern learning technologies.

In the blogpost she briefly outlines what she refers to as the key stages that should be considered in the design process when designing learning processes. Her intention is to clarify these processes to make more informed designs of learning [3]. In this early stage, the model is rather an overview of the stages and what is to be considered in each stage and the organization of the stages seems to be organized around the name of the model rather than in any order of chronology of time (see figure 1).

The model consists of 7 stages [3]:

Conceptualise: What is the vision for the learning intervention, who is it designed for, what is the essence of the intervention and what pedagogical approaches are used?

Capture: What Open Educational Resources are used and what other resources need to be developed?

Create: What is the nature of the learning intervention the learners will engage with? What kinds of learning activities will the learners engage with?

Communicate: What types of communication will the learners use?

Collaboration: What types of collaboration will the learners engage in?

Consider: What forms of reflection and demonstration of learning are included? Are the learning outcomes mapped to the activities and assessment elements of the learning intervention?

Consolidate: How effective is the design? Do the different elements of the design complement one another?

The 7Cs framework is visualised as follows (fig. 1):

\footnotetext{
${ }^{1}$ This is a literal translation from 'Undervisningsfaget dansk', which is a 40 ECTS subject chosen by the majority of the students enrolled in our teacher training programme. In 2009, when this subject was one of three subjects students had to choose, $65 \%$ chose 'Undervisningsfaget Dansk' [24). The numbers for 2016 are at this point not known.
} 


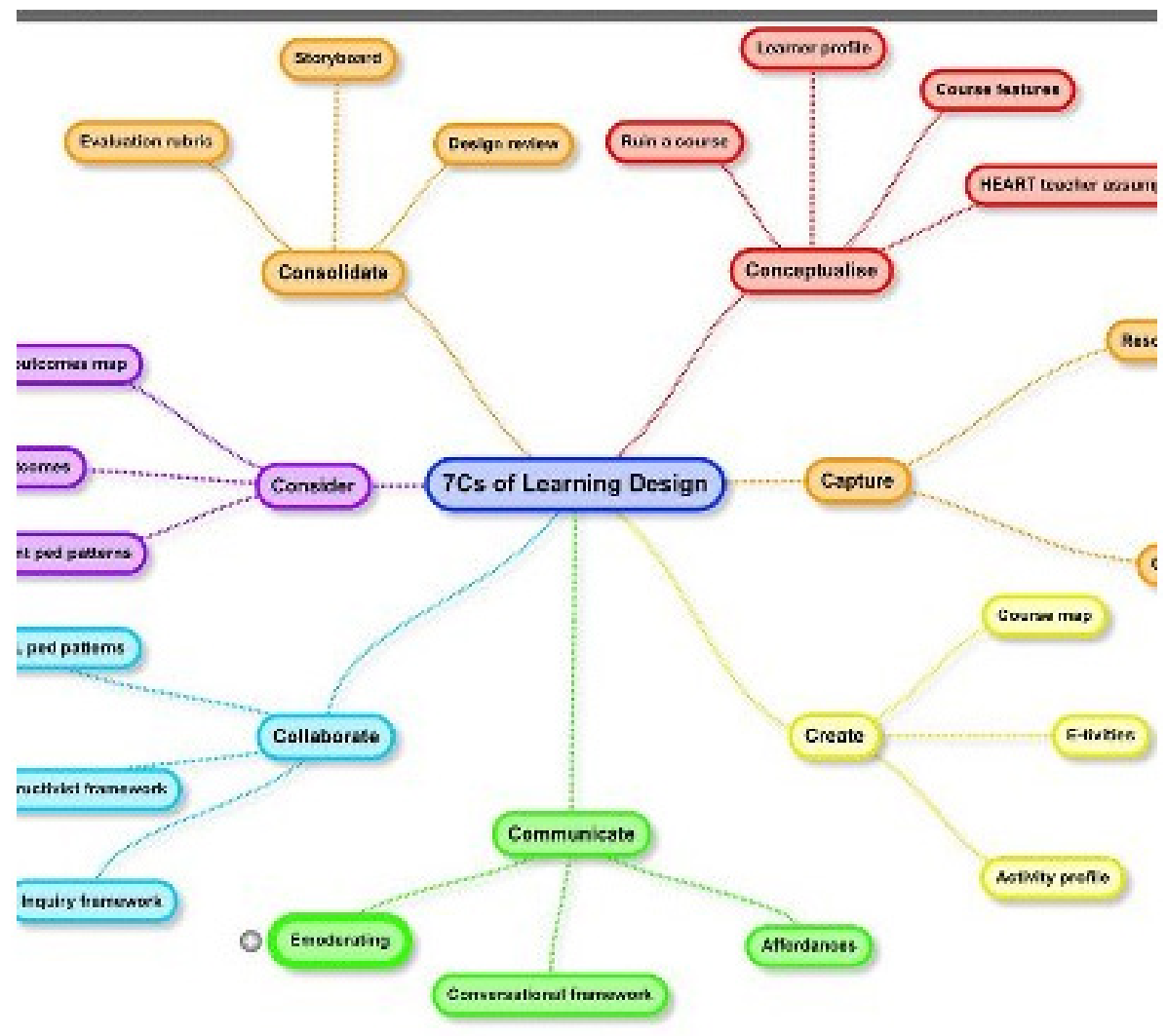

Figure 1. As can be seen from the figure above, there is no chronology in this first version of the framework [3]

In collaboration with Allejando Armellini and Gabi Witthaus among others, the framework was revised, and in February 2012 Armellini described their thoughts about the new version of the framework in another blogpost [4].

The model (shown below) now has some kind of chronology, as there is a circular course, which indicates a repeated process within the framework. The key stages are now named with verbs instead of nouns, thus indicating that the design process is an active process. In the blogpost, it is underlined that the model is created for designing learning processes that includes the use of technology, as Armellini states: "Each of the seven Cs has activities and technologies attached to it. For example, Capture has OER repositories as part of the resource audit; Communicate has Adobe Connect or Blackboard Collaborate (synchronous), as well as discussion forums (asynchronous); Consider may make use of blogs, etc." [4]. The model is thus explicitly seen as a tool to use when designing e.g. MOOCs and is also often discussed in connection with the development of MOOCs or other formats involving digital technologies [3].

This version of the framework is visualised as follows [5]:

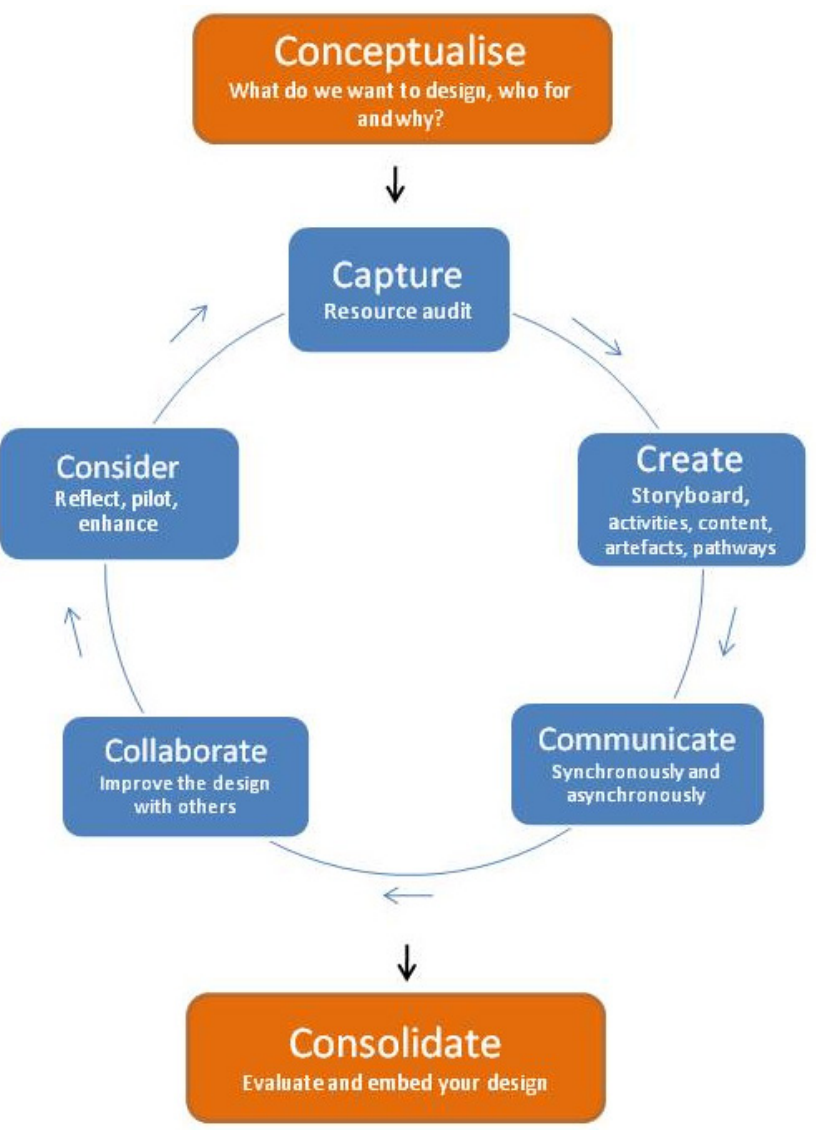

Figure 2. The 7Cs framework from 2012 [4]. 
The iterative process is indicated between the stages "Capture, Create, Communicate, Collaborate and Consider" and the arrows now indicate the process as chronologically from "Conceptualise" to "Consolidate" through the iterative processes. The iterative processes in the middle stages are not described or further elaborated on in the blogpost, and for this reason the thoughts that lie behind this change are unknown. However, we find that both the chronology as well as the iterative processes describes the design process very precisely. Designing learning processes will involve going back and forth between the different stages as mentioned before, e.g. it is possible that the chosen communication tool may have to be reconsidered after the ways in which learners can collaborate have been designed, or the resources to be used may have to be reconsidered after deciding how students are to reflect and demonstrate their knowledge and vice versa. Thus, we appreciate and approve of the changes made in 2012.

In 2013 Witthaus describes in her blogpost how the model has now changed into "a neat framework with four distinct phases namely 'vision, activities, synthesis and implementation"' [5]. The model presented in this blogpost is the one presented by Conole in her later papers [6: 74] where the "Create" stage has been changed to "Combine".

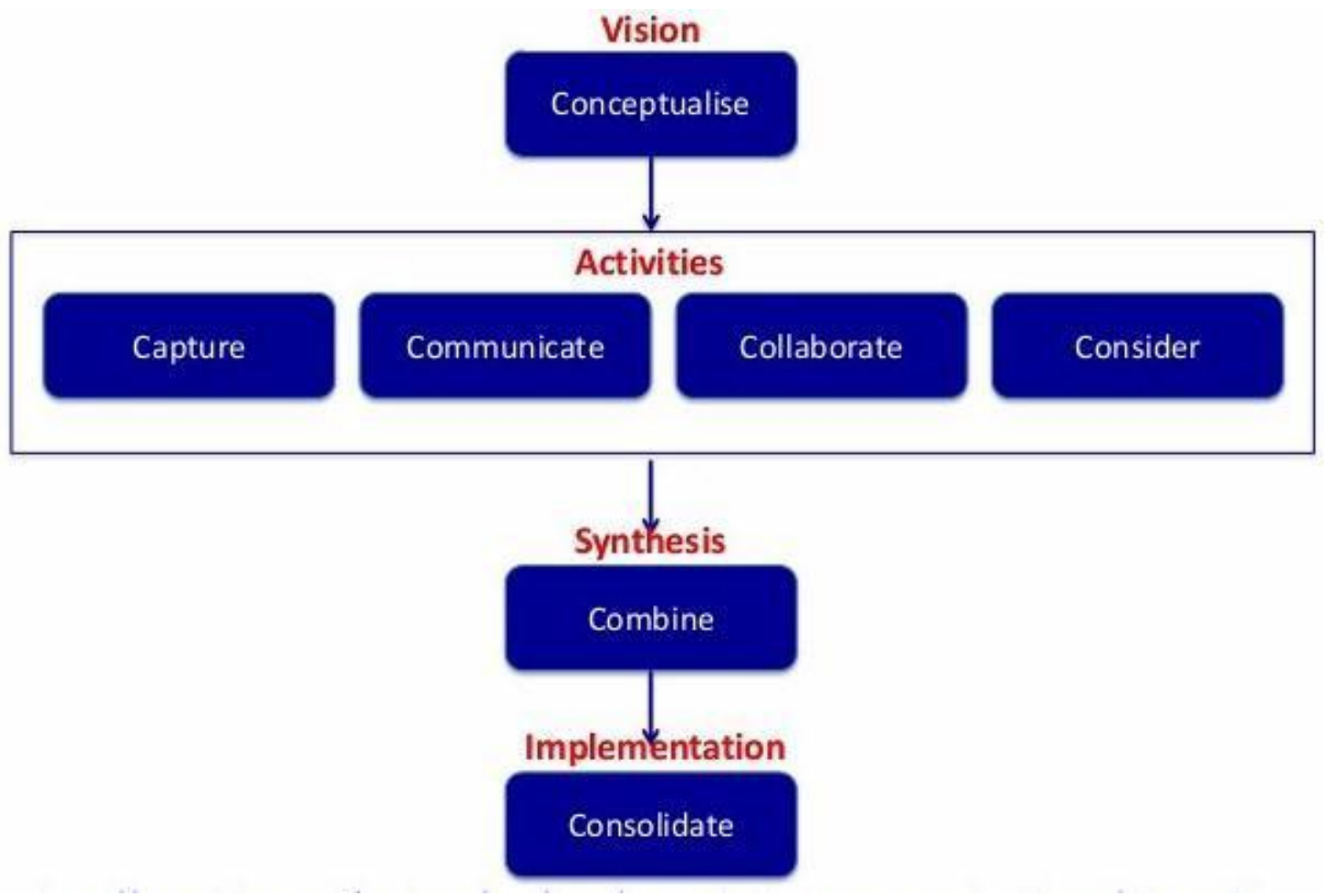

Figure 3. The latest version of the 7Cs framework [5].

The two most important changes are that the four phases containing the stages from earlier presentations of the model are introduced, and that the iterative process in the second stage has been left out. Again, there are no arguments for this change. As we see it, removing the dynamic and iterative idea of the stages in what is now the phase named "activities" means that the framework appears less dynamic and more linear than before. Besides, we find that it does not fully cover the actual design process of learning designs. Often teachers will move back and forth between the stages in the "activity" phase. We find the removal of the dynamic view of the model that was, as shown previously, present in the earlier versions, unfortunate, because it does not reflect the way most teachers design learning [7].

We have no insight into what caused these changes, but we find that it is important to bring this dynamic and circular process back into the model; designing learning processes is rarely or never a linear process, but rather a process in which the designer moves back and forth between the different stages, and maybe even between the four phases. Feedback processes can make changes even to the "vision" phase as well as to the other phases during and after the design of a learning process. To indicate this, we suggest that there should be double arrows between the "Vision", "Activities", "Synthesis" and "Implementation" phases as well as a circular process between the stages in the "Activities" phase.

What we claim is that the model should be turned from a static model of how to do learning design back into a model of a more dynamic learning design, recognizing both the iterative process in the 'Activities' phase as well as the eventual feedback processes in the whole design process. The framework below shows our perspectives on the design process: 


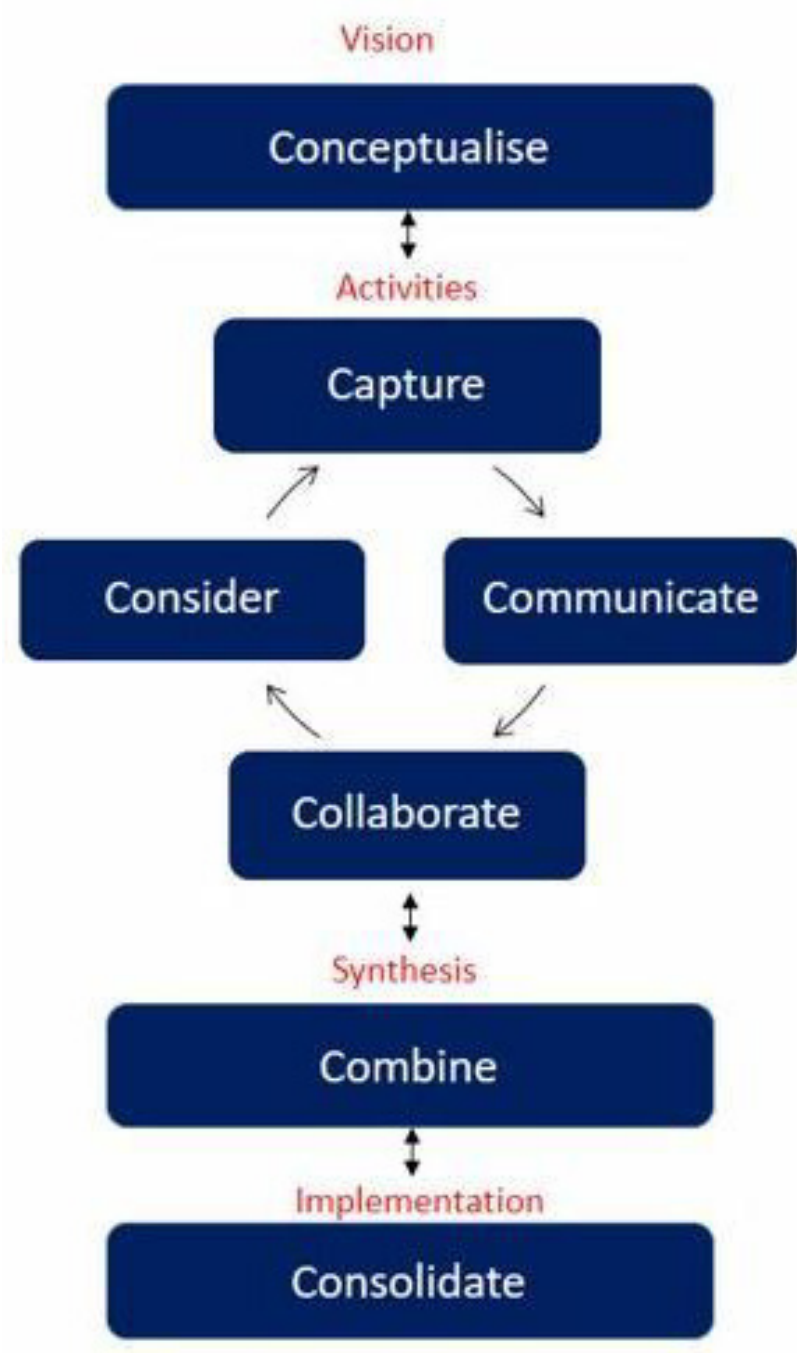

Figure 4. Suggestions for a revised version of the 7Cs framework

However, when evaluating the MOOC design by University College Absalon, we found that the framework seems to overlook the fact that MOOCs too are completed within a schooling discourse and that this influences the completion of the course.

\section{School as a Domain}

In the following we will look into the concept of school as a theoretical, semiotic domain. Semiotic domains are “...domains of specialized representations, modalities, knowledge, and practices" [8: 137]. One could also understand domains as discourses as Gee does; people act, speak, position themselves, take on attitudes etc. in a way that is adequate in each specific semiotic domain, and school can be seen as such a domain. Research into semiotic domains often distinguishes between the home domain as the situation, where children are socialized into everyday life, and (a) specialized domain(s) in which children are socialized into various domains as workplaces, recreational activities, religious communities etc. [9: 11,10:
29-38,11: 153ff,12: 42].The abovementioned researchers also include school as a special domain. School is seen as an important domain that students must be socialized into to fit into society in general, and some theorists see school a domain that maintains culture and power [13: 8]. Gee frames this acting, talking and positioning oneself as 'doing being' someone in the specific discourse. So acting to be accepted in a school discourse means doing being as a student. Traditional elements that are seen as a school discourse or school domain is 'doing being' a student who is obliged to e.g. attend class and to do homework.

Ulriksen [14] describes this in a slightly different way, when he uses the concept "The implied student", which is based on Isers concept "The implied reader" $[15$, for a discussion on this concept]. Such an implied student is defined in two dimensions. On one hand, the implied student is the expectations from institutions and people to behave like a student within the domain. On the other hand, students themselves must actively act in a manner expected and accepted in the domain, quite close to Gees 'doing being' [11]. It is notable that this 'doing being' is not seen as something that one must do, but rather as something one implicitly does without thinking about it [14: 522].

\section{Personalized Learning Paths}

In the school as a domain, the curriculum plays a crucial role. The word "curriculum" stems from Latin and translates into "a race" or "the course of a race" (which in turn derives from the verb "currere" meaning "to run" or "to proceed"). Pushing it to extremes, one may add that in the school as a domain students are expected to complete "the course of a race", i.e. their studies, at the same pace by studying the same contents in much the same manner to reach the same goal, usually in the form of a number of shared learning objectives. Paradoxically, we also know that students learn in different ways and that their personal prior knowledge is a highly influential factor in the learning process [16].

Consequently, different approaches to tailoring teaching to individual needs have emerged. Most notably the concept of differentiation has been introduced, where a variety of teaching methods are used to meet the individual needs of students who share the same learning goals. Likewise, the concept of individualization addresses students with the same learning goals, but this approach differs from differentiation in that students can move forward at their own pace and relate to specific contents or activities in different ways [17]. But what if students do not share the same learning goals and bring with them radically different degrees and types of prior academic knowledge? This is often the case in continuing adult education and here personalization offers promising opportunities in education. Personalization is teaching, where students have different learning objectives, depending on their prior knowledge and learning needs, and where the learning 
design adapts according to the specific learning needs of individual students. Personalization thus depends on the use of learning management systems, which can perform or support personalized adaptation. Research has shown that adaptive and personalised learning designs tend to have a positive effect on students' learning outcome [18]. In the following, we will look into an adaptive learning design in the form of a MOOC that allows for students to create their own personalized learning paths.

\section{The Problem of Schooling and Personalized Learning Paths}

In our MOOC, which was designed as a so-called SPOC [Small, Private, Online Course, see ,19], several features must be considered. Firstly, the SPOC was designed so that students can create a personalized learning path, which ideally is supposed to be unique for each of them [see e.g. , 20, for further discussion]. The students accepted into the SPOC are supposed to be trained teachers with at least two years of experience. In reality the students seem to have a variety of backgrounds ranging from very little experience to more than 20 years of experience. This makes the idea of a personalised learning path even more necessary. On the other hand, the SPOC ended up being organised as a blended course, combining face-to-face classes with online studies. This seems to frame the learning process even more into a traditional 'schooling' frame [2].

The whole "schooling situation" thus changes the idea of the original SPOC with its opportunities for personalized learning to a more traditional teaching and learning situation with face-to-face classes, every student having the same lesson plan to follow and the same homework to do. On this background, we assume that both students and teachers are very easily forced into acting the way students and teachers are expected to act inside the school discourse. In the following we will support and strengthen this assumption with data from one of our SPOCs, but first we will describe the way the SPOC was intended and implemented as a possible individual learning environment.

\section{Being a Student in an Absalon SPOC}

The SPOC designed for in-service teacher training was aimed at providing each student with their own learning path. As a starting point, in our SPOC, the students were to take a self-assessment test to determine which parts of the course they should follow. Each student then received a competency profile, as exemplified below, describing each of the content areas of the subject:

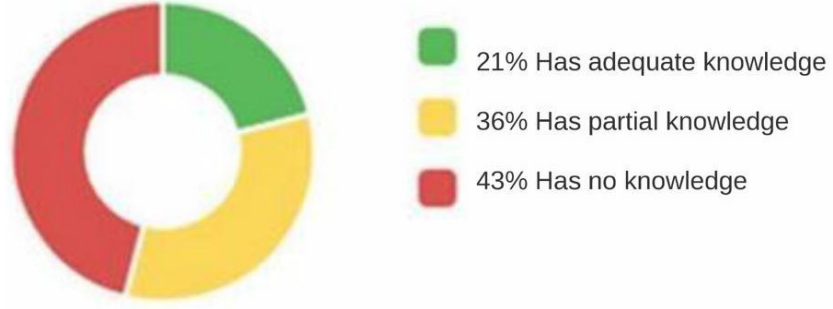

Figure 5. Example of a student's competency profile

The competency profile sums up which areas of contents the student hold knowledge about before entering the SPOC. In this example the red colour (43\%) indicates subject content that the student has very little knowledge about beforehand. The yellow area (36\%) indicates subject content that the student has partial or some knowledge about. The green area $(21 \%)$ indicates subject content that the student has much - in the sense of adequate - knowledge about, which means that these content areas can be skipped when studying the subject. Each of the students had different and personalized learning profiles that pointed directly at the parts of the SPOC which each student should study. Based on this self-assessment test, which was supplemented with a dialogue with an educator at the teacher training program, the personalized learning paths were scheduled.

The intention of the individual learning path is also emphasized on University College Absalon's web page, which emphasizes that the students can either work with all themes in all modules or (preferably) choose the themes that their individual competency profile has identified as relevant: "You can choose to work with all themes in all modules or you can choose to work with those themes that are relevant for you based on the result of your self-assessment" $[21]^{2}$.

The whole idea of the in-service teacher training thus clearly is to identify individual learning paths for all students. However, observing the actual teaching, we found that students seem to adhere to a traditional school discourse in both the online environment as well as face-2-face classes.

We observed that students expected a traditional school schedule as if they were a class of students sharing the same learning objectives, although in the learning design, the intention was to study individual themes and subjects as well as follow individual learnings paths. Since the students expected it, such traditional schedules were made for all classes with dates, themes for the teaching etc. These schedules also included reading suggestions that most students looked upon as traditional homework. However, these examples suggest a typical school behavior and

\footnotetext{
2 The text in Danish is as follows: Du kan arbejde med alle temaer i alle moduler eller vælge at arbejde med enkelte temaer, afhængigt af hvilke temaer, der på baggrund af selvevalueringens vidensprofil, er blevet udpeget som relevante. University College Sjælland was the name of University College Absalon until August 2017.
} 
shows that students actually "do be" students according to the expectations of the traditional school domain and not according to the MOOC discourse with its personalized learning paths.

The SPOC in the subject Danish was organized as four modules, which each had 12 themes with various reading suggestions, assessment, tasks, etc. The reading suggestions for the face-to-face classes were the same as those in the SPOC, and the face-to-face classes included references and discussion about the texts. Attending all classes was not necessary if the students followed their own learning path in the SPOC, and it was not obligatory either.

Still the students communicated with the educator e.g. through email, and used this to explain, why they did not attend a particular class "I was on a field trip to Berlin with my grade 8 classes last Friday and that is why I couldn't attend class this day" (email correspondence between educator and student) $)^{3}$, and the follow-up correspondence shows how this student sees himself more like a pupil than a student with his own individual learning path, once again explaining why he did not attend: " $H i X X, I$ did not attend, as previously noted, because of a field trip, and I therefore have a couple of questions:..." (E-mail correspondence between educator and student) ${ }^{4}$. These examples show that the students see themselves as being part of a school discourse, thus having to explain why they did not attend class.

However, the educators also acted like teachers in a traditional school discourse. The following quote is from an email sent to the students after a face-to-face class, showing how the educator thinks of the class as one group with the same learning tasks and learning goals: "Thank you for a great day! Tomorrow, you need to bring the teaching book Mundtlighed - teori og praksis. See you!'(Communication on the Moodle platform, August 2015 , emphasis in the original text) ${ }^{5}$ or this citation, showing that everyone is supposed to follow the same schedule: "I have published the revised schedule for you" (communication on the Moodle platform, August 2015, our emphasis) ${ }^{6}$. The educator also uses expressions such as "we" when referring to the students and the educator, thus emphasizing the idea of a group of similar students with similar needs and learning needs: "When we meet on friday...", "We will focus on..." and "...together we will look at..." (Communication on the Moodle platform, 19/10 2015, our underlining).

\footnotetext{
${ }^{3}$ Literally translated from: Jeg var på lejrskole i Berlin med mine 8. klasser i fredags, derfor kunne jeg desværre ikke være til undervisning.

${ }^{4}$ Literally translated from: Hi XX, Jeg var der som sagt ikke sidste fredag pga. lejrskole og har derfor lige to spørgsmål:...

Translation from: Tak for en god dag! I morgen behøver I blot at medbringe bogen: Mundtlighed - teori og praksis. Vi ses!

${ }^{6}$ From: Jeg har lagt en revideret undervisningsplan ud til jer.
}

Aspects of student behavior can also be observed in the face-2-face classes. The in-service teacher students, for instance, automatically position themselves in a classroom way as students, when entering a classroom, and automatically accept the classroom communication traditionally found in classrooms. This includes that the college educator is positioned in front of the white board, while students sit facing towards her in rows, and she speaks the most of the time and decides who to speak next (observation). To avoid such schooling behavior in a face-2-face environment will be quite difficult since the way the class is physically arranged solidify the schooling discourse.

As can be seen from our studies, a "schooling" frame means that students and teachers accept the rules of the school domain, and that students as well as teachers automatically occupy positions as "student" and "teacher" with what it entails such as e.g. 'schooling' communication, attitudes and 'doing beings'. When our SPOCs are combined with face-to-face classes, this situation seems to be unavoidable and can be observed in many SPOC subjects at University College Absalon. This could be called a design mutation, and must be taken into consideration [23]. The 7Cs framework does not account for this situation either, and since we find this is more or less unavoidable in blended learning or face-to-face situations, we suggest that the 7Cs model should be refined according to this.

\section{The 7Cs Framework - A New Model}

The implications for this 'schooling' frame is, amongst others, that students tends to NOT design and follow their own individual learning path, but rather, they follow a shared, teacher-instructed learning path through the whole course. In this sense, we point to the fact that the intended design of our SPOC has undergone significant changes when implemented.

The 7Cs framework should therefore be considered within a schooling frame, and we have thus revised the framework (see figure 6 below). In this version, we assume that the Vision phase is not necessarily affected by the schooling frame, whereas we find that in the Activities, Synthesis and Implementation phases this should be taken into consideration when designing blended MOOCs/ SPOCs. 


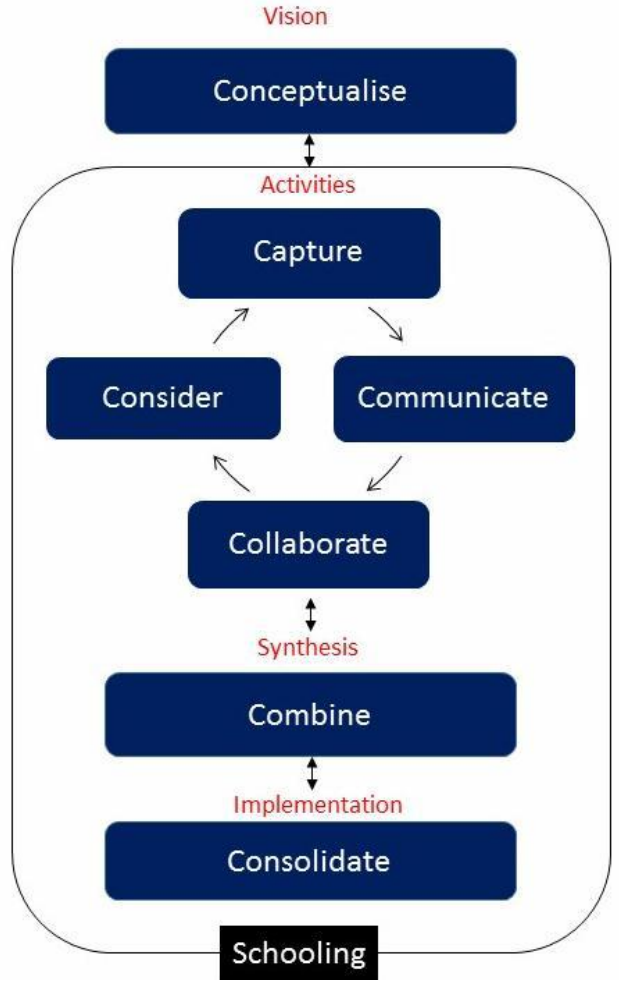

Figure 6. Revised version of the 7Cs framework. The concept of 'schooling' refers to schooling as a discourse in which students and teachers accept the rules of the school domain and behave in accordance with what is expected of them.

What we suggest is that the three phases of the model are framed in a school discourse visualized by an actual frame around these phases to indicate that when design the intended design, one must always consider the way the schooling discourse will influence the design.

\section{Conclusions}

As we have shown, the 7Cs framework should first and foremost be turned back into a dynamic learning design framework by adding double arrows between the phases and by reviving the iterative process in the 'Activities' phase to fully illustrate the ongoing feedback mechanisms in the design process. Furthermore, based on our analyses of the implemented design of a blended MOOC, the 7Cs framework should visually include and incorporate the influence of a school discourse as a discourse with great implications for the implementation of the intended design of the MOOC, especially in blended contexts.

Using this revised 7Cs framework, educational designers should remember to include the discourse of schooling when designing learning processes, meaning that it might have great impact on the implemented design when designing blended courses, since it appears that students as well as educators seem to very easily undertake traditional doing beings associated with their positions. Intending more personalized learning paths thus must be very carefully investigated and carried out in the design to be implemented.

\section{Further Research}

Further research should be done into the implications and impact of the schooling discourse on adaptive and personalized learning designs. We would recommend that empirical studies are carried out to support the theoretical reflections that we have put forward in this article and to further engage in developing new and better frameworks to support designers in designing adaptive, personalized and blended learning designs.

Also, looking into how to actually design MOOCs with a personalized learning path within a blended context is relevant. We believe that our revised $7 \mathrm{Cs}$ framework could be helpful in this relation, but further research is needed.

Furthermore, we believe that the school discourse might actually also influence students and educators doing being in MOOCs that do not involve face-to-face teaching. This should be investigated by further empirical studies of implemented and attained MOOC designs.

\section{REFERENCES}

[1] McKenney SE, Reeves TC. Conducting educational design research. New York: Routledge; 2012. x, 244 illustreret.

[2] Christiansen RB, Gynther K, Petersen AK. Changing Paradigms: From Schooling to Schools as Adaptive Recommendation Systems. Univers J Educ Res [Internet]. 2017 [cited 2017 Nov 14];5(11):2081-91. Available from: http://www.hrpub.org

[3] Conole G. Update on the 7Cs of learning design framwork [Internet]. e4innovation.com. [cited 2016 Jan 1]. Available from: http://e4innovation.com/?p=616

[4] Armellini A. Carpe Diem: the 7Cs of design and delivery [Internet]. Institute of Learning Innovation Blog. 2012 [cited 2016 Jan 1]. Available from:

https://beyonddistance.wordpress.com/2012/02/07/carpe-di em-the-7cs-of-design-and-delivery/

[5] Witthaus G. 7Cs update - the toolkit takes shape [Internet]. Institute of Learning Innovation Blog. 2013 [cited 2016 Jan 1]. Available from:

https://beyonddistance.wordpress.com/2013/01/14/7cs-upda te-the-toolkit-takes-shape/

[6] Conole G. A new classification schema for MOOCs. Int J Innov Qual Learn [Internet]. 2014;(3):65-77. Available from: http://innoqual.efquel.org/current-issue/

[7] Laurillard D. Teaching as a design science: building pedagogical patterns for learning and technology. Neew York: Routhledge; 2012. 226 p.

[8] Gee JP. Learning in semiotic domains. A social and situated account. In: Prinsloo M, Baynham M, editors. Literacies, 
Global and Local. John Benjamins Publishing Company; 2008. p. 137-49.

[9] Barton D, Hamilton M, Ivanic R. Situated literacies: reading and writing in context. Literacies. London: Routledge; 2000.

[10] Buch B. Tekster og genrer på erhvervsuddannelserne - med særligt henblik på overgangen fra grundskole til erhvervsuddannelse [Internet]. [Copenhagen]: Aarhus Universitet/Aarhus University; 2015. Available from: https://dansksaadan.wordpress.com/ph-d-afhandling/

[11] Gee JP. Social linguistics and literacies: ideology in discourses. 4. London and New York: Routledge; 2012.

[12] Hetmar V. Klasserummet som kulturelt felt. In: Østern A-L, Heilä-Ylikallio R, editors. Språk som kultur - brytningar i tid och rum. 11th ed. Vasa, Finland: Pedagogiska Fakulteten; 2004. p. 31-50.

[13] Brown S, Collins A, Duguid P. Situated Cognition an the Culture of Learning. Educ Res. 1989;18(1):32-42.

[14] Ulriksen L. The implied student. Stud High Educ. 2009;34(5):517-32.

[15] Weinreich T. Den fortællende læser - bidrag til udviklingen af teori om mødet mellem tekst og læser. In: Nedslag i Børnelitteraturforskningen, 2. Roskilde Universitetsforlag; 2001.

[16] Glaser R. Education and thinking: the role of knowledge. Am Psychol. 1984;39:93-104.

[17] Atkins DE, Bennett J, Fishman B, Gomez L, Kafai Y, Pellegrino J. Tranforming American Education: Learning Powered by Technology. Draft. NETP 2010 [Internet]. 2010 [cited 2016 Nov 4]. Available from: https://www.ed.gov/sites/default/files/NETP-2010-final-rep ort.pdf

[18] Akbulut Y, Cardak CS. Adaptive educational hypermedia accommodating learning styles: A content analysis of publications from 2000 to 2011. Comput Educ [Internet]. 2012 Feb; 58 (2): 835 - 42. Available from: http://www.sciencedirect.com/science/article/pii/S0360131 511002521

[19] Fox A. From MOOCs to SPOCs. Commun acm. 2013;56(12):38-41.

[20] Gynther K. Design Framework for an Adaptive MOOC Enhanced by Blended Learning: Supplementary Training and Personalized Learning for Teacher Professional Development. Electron J e-learning [Internet]. 2016;14(1):15-30. Available from: https://www.google.dk/url?sa=t\&rct=j\&q=\&esrc=s\&source $=$ web\&cd=1\&ved=0ahUKEwiV-rjn0rHPAhXJOSwKHe2e ABUQFggnMAA\&url=http\%3A\%2F\%2Fwww.ejel.org\%2 Fissue\%2Fdownload.html\%3FidArticle\%3D482\&usg=AF QjCNFjX0drF3mtxxoaQcOaiyltCuEE4g\&sig2=_mD7kwf WH11D91VDXGv3YA\&cad=rja

[21] University College Sjælland. MOOC - supplerende undervisningsfag [Internet]. University College Sjælland webpage. [cited 2016 Dec 7]. Available from: $\mathrm{http}$ :/ucsj.dk/folkeskolereform/viden-og-undervisningskom petence/mooc-supplerende-undervisningsfag/\#c76598

[22] Buch B. Dansk 4.-10. kl. Forårssemesteret 2016. 2016. p. 3.

[23] Hung D, Kin L, Huang D. Extending and scaling technology based innovations through research. Inspired by Technology, Driven by Pedagogy - A systemic approach to technology-based school innovations. 2010.

[24] Færre studerende og færre linjefagsvalg betyder fald i antal linjefag [Internet]. UVM/aktuelt. 2009 [cited 2017 Nov 1]. Available from:

http://www.uvm.dk/Aktuelt/ /UVM-DK/Content/News/Ud d/Videre/2009/Jan/090122-Faerre-studerende-og-faerre-linj efagsvalg-betyder-fald-i-antal-linjefag 